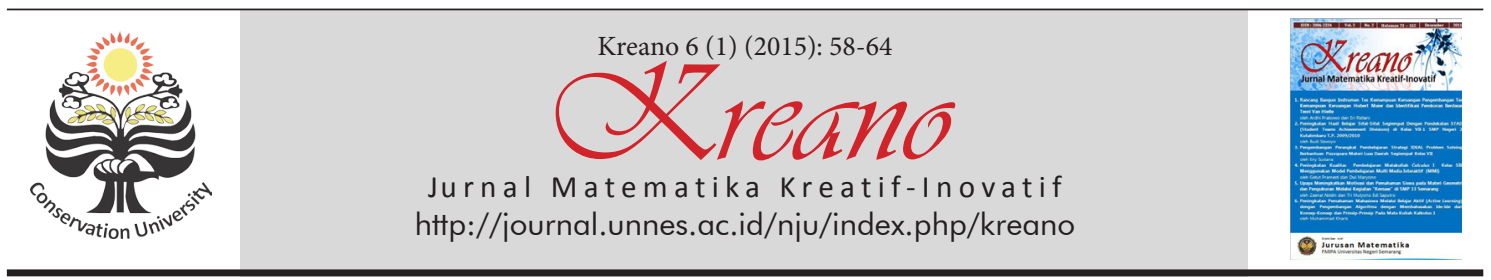

\title{
Growing the Character Values to Students through Application of Realistic Mathematics Education (RME) in the Social Arithmetic Learning
}

\author{
Amin Suyitno ${ }^{1}$ \\ 'Lecturer of Mathematics Education Study Program, Semarang State University \\ Email: aminsuyitno.unnes@gmail.com \\ DOI: http://dx.doi.org/10.15294/kreano.v6i1.4508 \\ Received : August 2015; Accepted: September 2015; Published: September 2015
}

\begin{abstract}
Educating students at the Basic Education level is not only demanded that the students are clever, but there are also other demand which no less important that is to educate so that students have a good character value. Educating the students to have a good character value is started from home, school, and community. In school, educating character to students is not only the duty of teachers of Religion or Civics class, but also the duty of all teachers, including the teachers in Mathematics. Math teacher does not need to hold special time for educating of character, but it can be integrated into any material taught, and also in different application of learning models. This paper examines how the efforts of mathematics teacher in educating of character to the students of Basic Education, especially in Junior High School through the application of Realistic Mathematics Education (RME) on the material of Social Arithmetic. Through presenting of the material of Social Arithmetic by RME learning model, students can be given a character education through the attitude of honesty, tolerance, discipline, cooperation, creative, independent, democratic, curiosity, love of peace, social care, responsibility, and so on. In conclusion, educational character values to students can be done by mathematics teacher through a variety of materials. One of them through presenting of the material of Social Arithmetic by RME learning model.
\end{abstract}

Keywords: Character Values, Social Arithmetic, Realistic Mathematics Education.

\section{INTRODUCTION}

Indonesia requires human resources in adequate quantity and quality as the main supporter in development. To meet the human resources, education has a very important role. This is in accordance with Law No. 20 Year 2003 on National Education System in Section 3, states that the national education serves to develop the ability and shape the character and dignified civilization in the context of the intellectual life of the nation. National education aims to develop the potential of the students to become a man of faith and fear of God Almighty, noble, healthy, knowledgeable, capable, creative, independent, and become a democratic citizens and responsible.

Character education aims to improve the quality of the implementation and results of school education towards achieving the formation of character and noble character of students as a whole, integrated, and balanced, appropriate to competency standards of graduation. Through character education, it is expected that students from elementary through high school/vocational able to independently increase and using the knowledge, study and internalize and personalize the character values and noble character so that manifest in everyday behavior.

Character values education which integrated in the learning are the introduction of values, facilitation in gaining the awareness of the importance of values, and internalisation of values into the daily behavior of students through a learning process, both of which take place inside and outside of class in all subjects. Basically, learning activities, in addition to making students master the competencies 
(material) that are targeted, it is also designed to make students recognize, realize/care, and internalised the values and makeit as behavior. For example, able to communicate and interact effectively and politely, understand the advantages and disadvantages of self, but also able to demonstrate a confident attitude. As a math teacher in primary education, especially in junior high school, the teacher should be able to become a facilitator of formation of character values of this nation through the application of appropriate learning models.

Competencies that must be owned by the students at all levels, including the realm/ field of cognitive, affective, and also skills. So, educate students at the level of junior high school students, not only required to make students proficient in the field of cognitive, but also there are other demands which no less importantly, the affective field that educate students in order to have the values of good character. Instilling the values of good character, must begin at home, at school, and community environment of students. In school, educate students character is not only the duty of Religion or Civics teachers, but also the task of all teachers, including teachers in Mathematics. Math teacher does not need to hold special hours and a special time to educate the student's character, but can be integrated in any material/subject, and also can be integrated in different application of learning models. This paper, examines how the efforts of teachers of mathematics lessons in educating the character of junior high school students through the application of Realistic Mathematics Education (RME) learning models on Social Arithmetic material.

\section{Character Values Education}

Character values education in Indonesia has been explicitly implemented since 1964 curriculum [6], with subjects known as Character lesson. But in its development, character education integrated into the lessons of Religion and Pancasila Moral Education. Explicitly, the teachers outside both of these subjects as not burdened with the duty to educate students in the field of character education.

Furthermore, after the corruption began rampant, fights between villages began to spread, fights between youths began to fre- quent, likes drinking began to evolve, various licentious acts began to appear, and even began to appear thinking to establish a state in the Homeland, then start there discourse to bring back aspects of the attitude assessment/affective in the student report. However, in the 1994 curriculum, the discourse of it only appears in the first semester. Furthermore, Kemdiknas beginning in 2010 explicitly require the teacher to insert any character values in the learning process.

Based on the book of Teacher's Guide Character Education in Junior high school (Ministery of National Education, 2010), there are 18 character values that need to be invested by the teacher to the students, namely: (1) religious, (2) honest, (3) tolerance, (4) discipline, (5) hard work, (6) creative, (7) independent, (8) democratic, (9) curiosity, (10) the national spirit, (11) love of the homeland, (12) appreciate the achievements, (13) friendship/communication, (14) love peace, (15) likes to read, (16) care for the environment, (17) social care, and (18) responsibility.

\section{RME Learning Model}

In Indonesia, Realistic Mathematics Education (RME) is often called the Indonesian Realistic Mathematics Education. RME learning model is based on the premise of Freudenthal [5] who wrote "Mathematics must be connected to reality and mathematics as human activity". This thinking is in line with Hardi Suyitno's writing [7], a professor of Philosophy of Mathematics who wrote that mathematics has a relationship with the real world. In fact, reaffirmed that based on the value of the philosophy of mathematics, then people will not be able to rule the world if people are not good at math. According to Zulkardi [15], the application of RME associate real life as a starting point in the study of mathematics. Mathematics is given informally first, students are actively involved since the beginning of the learning, then reinforced by the provision of material formally by the teacher.

\section{RME Characteristics}

RME characteristics are (1) the use of real context (associated with real life) as a starting 
point to learn mathematics; (2) emphasize the completion informally before using the formal way or using the formula; (3) there is an attempt to associate fellow topics in math; (4) respect for diversity of the student answers and the student contribution.

\section{Syntax of RME Application in schools}

Syntax of RME Application in schools is as follows. Before a lesson (subject matter) is given to the student, the student is given the activities planned (can through practice simulation, singing, teaching aid, mini workshop, games, or giving a preliminary problems about 1-2 contextual/realistic problems) directing that students can find or construct their own knowledge. All activities are designed can be done by students informally or trial and error based on an appreciation or a specific way of students (due to the material or algorithm that question has not been given by the teacher to the student).

Furthermore, teachers observe/assess/ examine the work of the students. Teachers need to respect the diversity of students' answers, then the teacher can ask one or two students to demonstrate their findings (how to solve it) in front of the class. Then, with question and answer, the teacher can repeat students' answers, so that other students have a clear picture of the mindset of students who have completed the problem/questions.

After that, the teacher explained the subject matter that support issues/problems which just discussed (or activities that are just done), including providing information about the exact algorithm to solve the problem. With this activity, the students are expected to finally be able to construct their own knowledge. However, teachers still need to provide sufficient direction if it is necessary.

Although thought to construct his own knowledge is a natural process, but if left alone, it is often biased, distorted, partial, uninformed, and potentially prejudiced; but the excellence in thie mind should be cultivated. Scriven and Paul [12] asserted that: Thinking is a natural process, but left to itself, it is Often biased, distorted, partial, uninformed, and Potentially prejudiced; excellence in thought must be cultivated.

\section{Social Arithmetics Material in El- ementary Education}

Figure 1 is a part of Mathematics Book of grade VII Semester 2 Revised Edition 2014 at page 81. Understanding the Social Arithmetic, written at the beginning of the discussion.

\section{Part 1:}

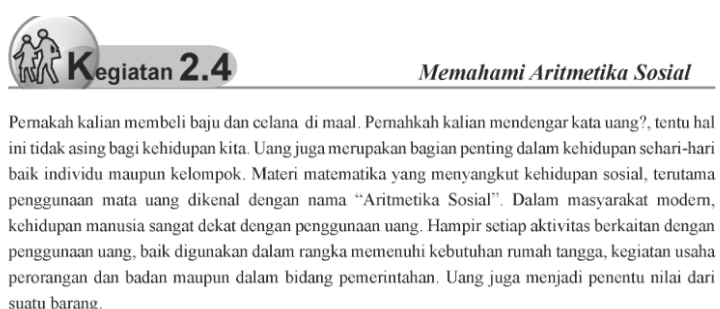

Fig. 1 First Part of Mathematics Book

Based on the description in the above part of the book, the Social Arithmetic interpreted as a mathematical matter concerning social life, particularly the use of currency. Thus, Social Arithmetic is a matter close to our daily life, such as: Calculating the Overall Value, Value Per Unit and Partial Value, buying Price, Selling Price, Profit, Loss, Discount, Gross, Tara and Net.

To further clarify this matter, you should first understand the characteristics of Social Arithmetic.

\section{Characteristics of Social Arithmetics}

Social Arithmetic characteristics are as follows. (1) Social Arithmetic material is always related to everyday life. Social care attitude, friendship, and tolerance is needed in the Social Arithmetic applications in everyday life. (2) Social Arithmetic material is related to the economy or trade and transactions of sellingbuying. The transactions required cooperation, courtesy, and communicative. (3) In this material of Social arithmetic, load the understanding of the overall price, the price per unit, and the partial prices. It also contains about the buying price, selling price, profit, loss, discounts, gross, tare, and net. So the character of discipline, creative, and social care is needed.

\section{Character Value Education Through RME in Social Arithmetic}


In the implementation of Curriculum 2013, the character values need to be instilled explicitly. Suyanto [13] and English [4], also suggested that the teachers should be able to choose an effective and joyful learning model, so that the values of the characters can be implanted into the students in a subtle manner, polite, and did not seem to impose. In student book of Mathematics VII Curriculum 2013 Revised Edition, Social Arithmetic is given to students in Semester 2.

In the book precisely so reflected the application of RME, ie, before the subject matter of Social Arithmetic formally given, the students are given a stimulus task/problem that is done informally. The philosophy underlying the Realistic Mathematics Education (RME) is that students should develop their mathematical understanding by working from the context that makes sense to them. Dickinson, P and Hough, S [2] wrote that "The philosophy underpinning Realistic Mathematics Education (RME) is that students should develop Reviews their mathematical understanding by working from Contexts that make sense to them".

Examples of parts of orders in student book of Mathematics VII Curriculum 2013 Revised Edition as follows, reflecting the application of RME learning models and is accompanied by character values education.

1. Before the lesson begins, students should be encouraged to pray according to their religion. This is the cultivation of religious values.

2. Students are given the task/problem informally in accordance with the rules of the philosophy of RME, before the Social Arithmetic material is given formally. This is the characteristic of RME learning.

3. Students are trained to think independently through the stage of questioning.

\section{Part 2:}

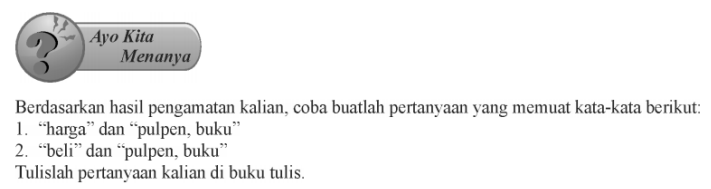

Fig. 2 Second Part of Mathematics Book
4. Furthermore, as the RME application form, students are given a contextual problem and asked to find a solution independently beforehand. In addition to the value of selfreliance, the teacher can instill the values of discipline, hard work, and responsibility.

Part 3:

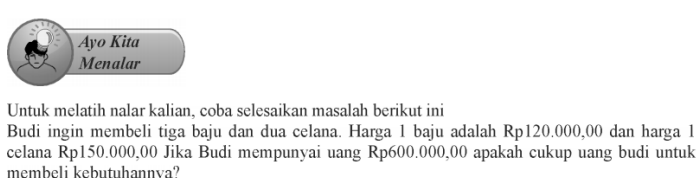
Budi ingin membeli tiga baju dan dua celana. Harga I baju adalah Rp $120.000,00$ dan harga
celana Rp150.000,00 Jika Budi mempunyai uang Rp600.000,00 apakah cukup uang budi untuk membeli kebutuhannya?

Fig. 3 Third Part of Mathematics Book

5. Next, the students were asked to discuss with friends. Through this discussion, students were educated with the values of the good characters: Friendly/communicative, tolerance, democracy, and curiosity.

Part 4:

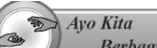

Diskusikan jawabanmu dengan teman sebangku, kemudian coba presentasikan di depan kelas.

Fig. 4 Fourth Part of Mathematics Book

6. Furthermore, in accordance with the thinking pattern of RME, students were asked to explore their own meaning of "buying price", " selling price", "profit", "loss", and other terms contained in the subject matter of Social Arithmetic. Here, teacher can trains students to have the values of $\mathrm{Cu}$ riosity, creativity, hard work, and self-contained.

From the explanation above, it is apparent how the subject matter of Social Arithmetic given to the students through the RME learning model, can also instilled the values of good character to students.

\section{Valuing of Character}

Character assessment in schools, including in the realm of attitude competence assessment. Character as part of an attitude, as well as an expression of values or way of life that is owned by someone. Characters can be 
formed, resulting in a change of behavior or action is expected. According of Permendikbud Number 104 of 2014, there are several ways that can be used to assess the student's character, among others, through observation, self-assessment, peer assessment, and journal assessment. Instruments used include a check list or the assessment scale (rating scale) accompanied rubric, the outcome of which is calculated based on mode. The following will describe the instrument that can be made of teacher in assessing the character based on observations. The characters of students' everyday recorded through observation using a format that contains of indicators of characters observed, both associated with the subjects or the general events. Observation of the characters associated with the subjects carried out by the teacher during the learning process, such as: tolerance, curiosity, hard work, responsibility, friendship/communicative, democratic, creative, discipline, selfcontained, and while a student is in school or even outside of school during behavior can be observed by teacher. Teacher can choose a character that is prioritized to be observed.

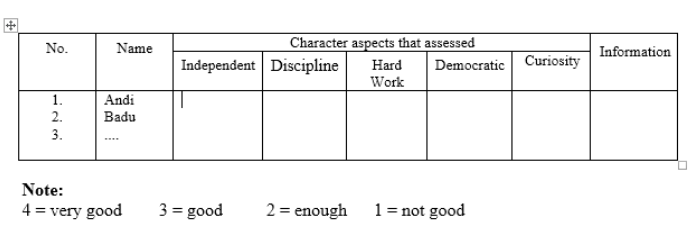

Fig. 5 Observation sheet of students character

The format above may be used on other subjects by adjusting the behavioral aspects that want to be observed.

\section{Application in a Classroom Action Research}

As the application of the ideas above, the authors have been conducting a research in the form of classroom action research (CAR).

\section{BACKGROUND OF RESEARCH}

Educate the students of junior high school, not only demanded that the students are clever, but there are also other demands no less importantly, namely to educate so that students have the values of good character.
Educate the students so that the students have a good character value, started from the home, school, and community. Therefore it is necessary for them to utilize RME in learning arithmetic Social at SMP 30 Semarang to instill character values to students.

\section{RESEARCH METHODS}

The research subject is Class IA SMP 30 of Semarang. This research was conducted in two cycles. Each cycle there are four phases: planning, implementing, observing, and reflecting.

\section{THE RESULTS OF RESEARCH}

Aminah and Suyitno [1] reported that the application of RME learning model with the subject matter of Social Arithmetic contained characters can increase the absorption of learning and activities for students at SMPN 30 Semarang.

In learning, before teacher starts a lesson, the teacher can explain the purposes of learning, according to the Basic Competence to be achieved, especially in the subject matter of Social Arithmetic in grade VII.

Here, described of application of RME learning model with the subject matter of Social Arithmetic contained character in SMPN 30 Semarang. Teacher preparations that needed: preparing of Observation Sheet for the measurement of the students character values, preparing materials for the simulation of practice in buying and selling, giving direction to the students about the procedures for communication/interview were polite, friendly, and programmed so that the purpose of the interview can be achieved.

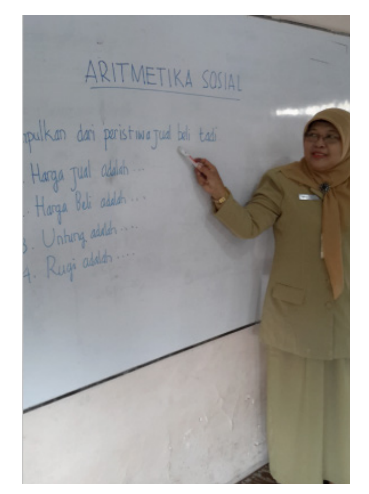

Fig. 6 Teacher gives a direction before the learning of Core Activities implemented. 
To explore their own of knowledge about the understanding of the selling price, buying price, profit, loss, discount, and so on, each students group can perform such activities appeared the photo below. Furthermore, the activities of students can do, among others: (1) ask the shop owner or the store manager cooperative school , (2) each group of students can practice of buying and selling in the classroom as a form of simulated activities of buying and selling in the market, or (3) after completion of the simulation, each group was asked to present his findings to the class.

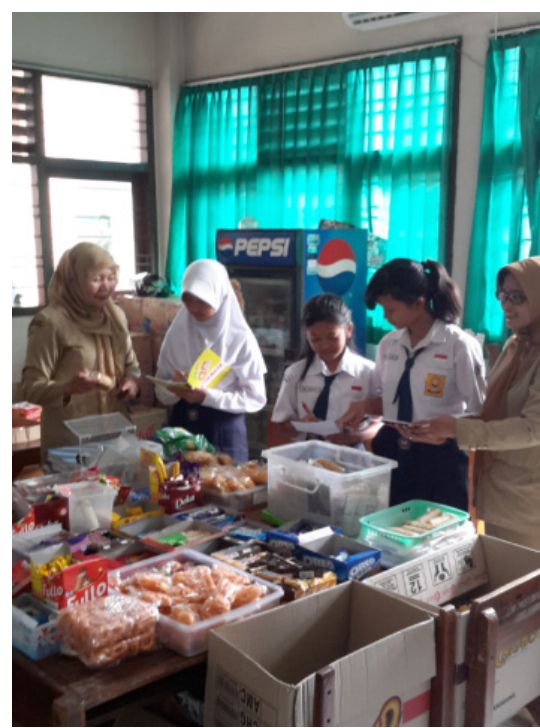

Fig. 7 Group of students conducted interviews with the manager of School Cooperative.

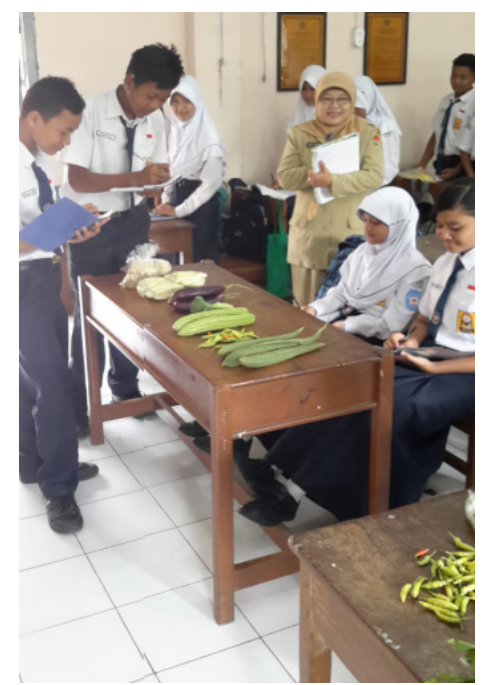

Fig. 8 Each group of students conducted simulations of buying and selling

In the simulation activity, the teacher has been able to embed and assess the characters on students through observation sheet. Further, each group was asked to present their finding to the class. Students or other groups with the teacher give feedback on results presentation. Duron, Limbach, and Waugh [3] wrote that: Feedback and assessment of learning are provided by the teacher in the final step of the model. Hopefully, the material can be absorbed well by the students.

\section{CONCLUSION}

Based on the description in this paper, it can be concluded as follows. (1) Math teachers of SMP/MTs, can present of Social Arithmetic material through a certain learning model, one of which is RME. (2) Social Arithmetic material, contains the values of character because it involves the social relationships between people. (3) When the teacher presents of material of Social Arithmetic through RME teaching model, teacher can educates and instill the values of noble character to the students. (4) How to judge the character can refer to Permendikbud Number 104, 2014.

Supplementary of Textbook need to be arranged in particular on the mathematics subjects in which includes portions are large enough to instill character education. Furthermore, Supplementary of Textbook is intended, should also be given the charge that not only includes the portion large enough to instill character education, but also able to foster a sense of nationalism and national values are high.

To achieve this, it can be followed up with the research collaboration involving developed countries like the United States which already have very much experience in growing sense of nationalism in society.

\section{REFERENCES}

Aminah, S. and Suyitno, A. (2015). Meningkatkan Hasil Belajar Siswa SMPN 30 Semarang Melalvi Aplikasi Pembelajaran RME dengan Materi Aritmetika Sosial Bermuatan Karakter. Report of Classroom Action Research. Semarang: SMPN 30 (unpublished).

Dickinson, P., \& Hough, S. (2012). Using realistic mathematics education in UK classrooms. Centre for Mathematics Education, Manchester Metropolitan University, Manchester, UK.

Duron, R., Limbach, B., \& Waugh, W. (2006). Critical 
64 Amin Suyitno, Growing the Character Values to Students through Application of Realistic Mathematics

thinking framework for any discipline. International Journal of Teaching and Learning in Higher Education, 17(2), 160-166.

English, L.D. (1997). Mathematics Education - Models and Processes. New Jersey: Lawrence Erlbaum Associates Publishers.

Freudenthal. (1991). Revisiting Mathematics Education. China Lectures. Dordrecht Kluwer: Academic Publishers

Hamalik, O. (1990). Pengembangan Kurikulum, Dasardasar dan Pengembangannya. Bandung: Mandar Maju.

Jumaisyaroh, T., Napitupulu, E. E., \& Hasratuddin, H. (2015). Peningkatan Kemampuan Berpikir Kritis Matematis dan Kemandirian Belajar Siswa SMP melalui Pembelajaran Berbasis Masalah. Kreano, Jurnal Matematika Kreatif-Inovatif, Vol. 5(2), pp. 157-169.

Kemdikbud. (2014). Nomor: 5496/C/KR/2014 dan Nomor: 7915/D/KP/2014 tentang Petunjuk Teknis Pemberlakuan Kurikulum Tahun 2006 dan Kurikulum 2013.

Kemdikbud. (2014). Buku Pegangan Siswa: Matematika
Kelas VII Semester 2 - Kurikulum 2013 Edisi Revisi. Jakarta: BSE.

Kemdiknas. (2010). Panduan Guru - Pendidkan Karakter di Sekolah Menengah Pertama. Jakarta: Direktorat Pembinaan SMP.

Permendikbud Nomor 104 Tahun 2014.

Scriven, M., \& Paul, R. (2004). The Critical Thinking Community. Retrieved November 28, 2005, from http://www.criticalthinking.org/pages/defining-critical-thinking/410. [Accessed, January 4, 2015].

Suyatno. (2009). Menjelajah Pembelajaran Inovatif. Sidoarjo: Masmedia Buana Pustaka.

Suyitno, H. (2014). Pengenalan Filsafat Matematika. Semarang: Penerbit FMIPA Universitas Negeri Semarang.

UU No 20 Tahun 2003 tentang Sistem Pendidikan Nasional.

Zulkardi. (2001). Realistic Mathematics Education (RME) dan Contoh Pengajarannya pada Aljabar Linear di Sekolah Menengah. Paper for Algebra Seminar VI at Unpar Bandung. 